Animal welfare

\section{Convention in tatters}

THE prospect of a European convention on the use of animals in research now seems more remote than ever. The parliamentary assembly of the Council of Europe, meeting last week in Strasbourg, failed for the second time to achieve the required twothirds majority when it voted on a report urging the council's executive body, the Committee of Ministers, to adopt the draft convention as soon as possible. In May this year, an earlier attempt to vote on the report, drawn up by $\mathbf{M}$. Bassinet, a French socialist, failed after the meeting was found to be inquorate. The Committee of Ministers will now probably refer the draft convention back to a reconstituted expert committee for detailed re-examination.

Ironically enough, the reason that last week's vote fell 7 votes short of the majority that would have placed the draft convention automatically on the ministers' agenda was that many delegates felt it did not go far enough in defining welfare guidelines. The existing text is so mild in its demands that only a minority of European countries would be affected. However, on the eve of the vote, Herr Genscher, the West German Foreign Minister, sent a telegram to the head of the parliamentary assembly saying that the draft convention would not be acceptable domestic pressure from the Greens might underlie this move, which was criticized in debate as an unwarranted interference.

The Bassinet report urged a new preamble for the convention which placed its requirements, such as they are, in a humanitarian context, as part of the cultural values of Europe. It also included new provisions for updating the convention as scientific knowledge progresses. Despite failing to recommend Bassinet's report, the parliamentary assembly did, however, reject a series of ammendments put forward by an Italian delegate, S. Fiandrotti, which would have outlawed the experimental use of animals.

The expert committee that drafted the convention back in the 1970 s is opposed to the changes urged by Bassinet, and their recommendation will be before ministers when they meet in November. Many welfare groups in Europe had thought that a weak convention would be better than none at all, but they have been disappointed even in this. On past form, it may now be years rather than months before the council eventually comes to vote on a convention. The British Government, however, has made it clear that it intends to introduce new legislation on the use of animals in research without waiting for the Council of Europe. A bill is being prepared and could, subject to availability of parliamentary time, be debated in autumn 1984.

Tim Beardsley

US National Institutes of Health The politics of new diseases

\section{Washington}

COMPETITION among various charitable organizations to have their own favourite disease incorporated in the name of a National Institutes of Health (NIH) institute has been a constant headache for NIH officials; earlier this year, NIH sought to forestall the latest pressures for instituteproliferation from the "disease of the month club" by commissioning a study of NIH's organizational structure by the National Academy of Sciences.

Last week, hearings called by the academy panel carrying out the study provided a graphic demonstration of what $\mathrm{NIH}$ is up against. A parade of representatives from professional, university and charitable organizations came to press their cases for a new arthritis institute, a new emphasis on minority groups' health problems, a new emphasis on rare diseases, a new emphasis on basic biomedical disciplines, and - surely the winner in the

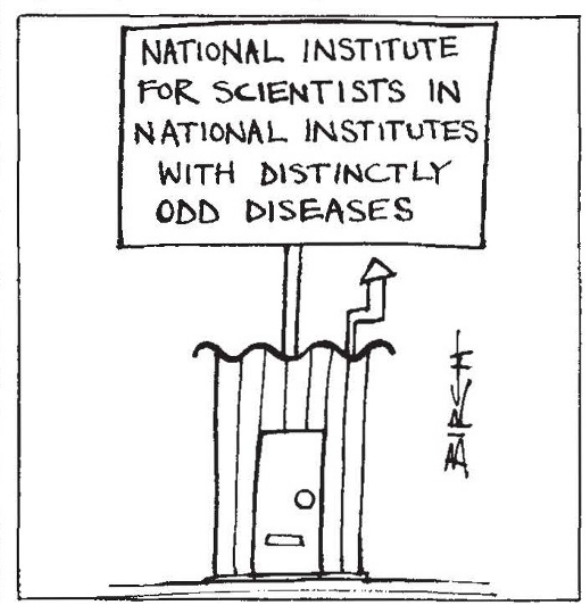

special-interest group competition - a new otolaryngology institute.

NIH officials maintain that the creation of ever more institutes with ever narrower focuses (the number now stands at 13) only makes for increased administrative burdens and scientific fragmentation. They are concerned, too, that current efforts to write into law specific authorizations for each separate institute will lead to political determination of research priorities; at present, NIH remains free to apportion a lump-sum appropriation largely as it sees fit.

The most immediate threat is a bill (HR 2350 ) pending on the House floor by Representative Henry Waxman (Democrat, California) would split NIH's spending authority into 19 separate line items. A substitute, which is to be offered by Representative James Broyhill (Republican, North Carolina), Edward Madigan (Republican, Illinois), and Richard Shelby (Democrat, Alabama) would keep NIH's free-wheeling spending authority intact.

NIH's allies in this fight, though, have their own special interests at heart, too. At last week's hearings, the chief opponents of disease-specific institutes and line-item authorizations were the professional medical and scientific societies drawn along disciplinary lines who fear that emphasis on specific diseases in NIH's structure (and the political clout in Congress they can command) undermines basic, disciplinary research. And a group called the National Organization for Rare Disorders, frankly admitting its inability to organize the political following that arthritis or diabetes can, proposed eliminating specific diseases from all of the institutes' names to prevent disproportionate support for the "politically powerful diseases",

The Arthritis Foundation - which, despite NIH's attempts to block it, has succeeded in winning the establishment of a new arthritis institute in all versions of the legislation pending before Congress takes the line that such highly visible signs of NIH's attention to politically popular efforts can only work to NIH's advantage in gaining congressional support for its total budget. "We must be opportunistic, see how we can take advantage of the system," said Frederick McDuffie of the foundation. "NIH must adapt to the political realities."

The wrangling between Waxman and Broyhill in the House has so far stymied action on the NIH authorization legislation, leading to the now familiar end-of the-fiscal-year scramble to pass a stop-gap spending measure. Efforts are said to be under way between Waxman and Broyhill to work out a compromise; meanwhile, NIH - along with the many other agencies that are still without authorization bills for fiscal year 1984 beginning on 1 October will be kept in business under a so-called "continuing resolution", The House has already voted to appropriate $\$ 4,200$ million for NIH in financial year 1984, a substantial increase over the current level. But under House rules, only authorized programmes may have their funds increased in the continuing resolution. NIH's research programmes operate under permanent authority, and thus should receive the increase for 1984 under the continuing resolution. But two important $\mathrm{NIH}$ programmes - training grants and extra mural grants to medical libraries - will have to be kept at 1983 levels in the continuing resolution until the authorizing legislation is passed.

In the Senate, NIH authorization legislation is being held up over a different dispute. Senator Bob Packwood, a liberal Republican from Oregon, is refusing to allow the bill to come to the floor until he can extract a promise that conservatives will not offer an amendment banning fetal research.

Stephen Budiansky 